\title{
HUBUNGAN PENGETAHUAN MURID KELAS III-VI DENGAN KEBIASAAN MENCUCI TANGAN DI SDN No.30/XI KOTO DIAN KEC. HAMPARAN RAWANG KOTA SUNGAI PENUH
}

\author{
Soviarni \\ Akademi Keperawatan Bina Insani Sakti \\ Email Korespondensi: 05.hannan2014@gmail.com \\ Disubmit: 24 Januari 2022 Diterima: 01 Februari 2022 Diterbitkan: 02 Februari 2022 \\ DOI: https://doi.org/10.33024/mnj.v5i2.5916
}

\section{ABSTRACT: CORRELATION OF KNOWLEDGE OF CLASS III-VI STUDENTS WITH HAND WASHING HABITS IN SDN NO. 30IXI KOTO DIAN KEC. HAMPARAN RAWANG KOTA SUNGAI PENUH}

Introduction: The habit of washing hands with soap is part of a healthy lifestyle which is one of the three pillars of development in the health sector. Based on the existing phenomena, it can be seen that school-age children have a habit of not paying attention to the need for hand washing in everyday life, especially when in the school environment. Based on the initial survey on August 5, 2021 by conducting guided interviews with 10 respondents. 7 of them do not have good habits and 3 of them have good habits.

Purpose: The purpose of this study was to determine the relationship between students' knowledge levels and hand washing at SDN NO. 30/XI Koto Dian Kec. Hamparan Rawang Sungai Penuh.

Method: This research is descriptive analytic with a cross sectional research design, which has been carried out at SDN No. 30/XI Koto Dian Kec. Hamparan Rawang, in October 2021. The population in this study were all students of SDN No. 30/XI class III -VI Koto Dian Kec. Hamparan Rawang by taking Accidental Sampling. data collection using a questionnaire distributed to respondents. Data analysis was univariate (frequency distribution) and bivariate (chi square).

Results: It is known that 31 (57.4\%) respondents have poor knowledge and 23 (42.6\%), mostly 30 (55.6\%) have bad habits and 24 (44.4\%) have bad habits. good, there is a relationship between the level of students' knowledge and the habit of washing hands at SDN No. 30/XI Koto Dian Kec. Hamparan Rawang with ( $p$ value 0.018 Odds Ratio $=4.583$ )

Conclusion: there is a relationship between the level of knowledge of students with the habit of washing hands at SDN No. 30/XI Koto Dian Kec. Hamparan Rawang, Sungai Penuh In 2021, nursing education is expected to increase knowledge about the importance of hand washing, which can be used as a basis for information. Schools are also expected to provide supervision in shaping personality in schools and can reduce the habit of not washing hands in students.

Keywords: Knowledge, Habits, Washing hands 
INTISARI: HUBUNGAN PENGETAHUAN MURID KELAS III-VI DENGAN KEBIASAAN MENCUCI TANGAN DI SDN No.30/XI KOTO DIAN KEC. HAMPARAN RAWANG KOTA SUNGAI PENUH

Latar Belakang: Kebiasaan mencuci tangan dengan sabun adalah bagian dari perilaku hidup sehat yang merupakan salah satu dari tiga pilar pembangunan bidang kesehatan. Berdasarkan fenomena yang ada terlihat bahwa anak-anak usia sekolah mempunyai kebiasaan kurang memperhatikan perlunya cuci tangan dalam kehidupan sehari-hari, terutama ketika di lingkungan sekolah. Berdasarkan survey awal pada tanggal 05 Agustus 2021 dengan melakukan wawancara terpimpin dengan menemui 10 responden. 7 diantaranya tidak memiliki kebiasaan yang baik dan 3 diantaranya mempunyai kebiasaan yang baik

Tujuan: Tujuan penelitian ini untuk mengetahui Hubungan Tingkat Pengetahuan Murid dengan Kebiasaan mencuci tangan di SDN NO. 30/XI Koto Dian Kec. Hamparan Rawang Kota Sungai Penuh

Metode: Penelitian ini bersifat deskriptif analitik dengan desain penelitian Cross Sectional, yang telah dilaksanakan di SDN No. 30/XI Koto Dian Kec. Hamparan Rawang, pada bulan Oktober 2021. Populasi dalam penelitian ini adalah seluruh Murid SDN No. 30/XI kelas III -VI Koto Dian Kec. Hamparan Rawang dengan pengambilan sampel Accidental Sampling. pengambilan data menggunakan kuesioner yang dibagikan ke responden. Analisis data secara univariat (distribusi frekuensi) dan bivariat (chi square).

Hasil: Diketahui responden berpengetahuan kurang baik 31 (57,4\%) dan berpengetahuan baik 23 (42,6\%), sebagian besar 30 (55,6\%) memiliki kebiasaan yang tidak baik dan $24(44,4 \%)$ memiliki kebiasaan yang baik, ada hubungan tingkat pengetahuan siswa dengan kebiasaan mencuci tangan di SDN No. 30/XI Koto Dian Kec. Hamparan Rawang dengan ( $\mathrm{p}$ value 0,018 Odds Ratio $=4,583$ )

Kesimpulan: Ada hubungan tingkat pengetahuan siswa dengan kebiasaan mencuci tangan di SDN No. 30/XI Koto Dian Kec. Hamparan Rawang Kota Sungai penuh Tahun 2021. Pendidikan keperawatan diharapkan dapat meningkatkan pengetahuan tentang pentingnya cuci tangan dapat dijadikan salah satu pijakan informasi Sekolah juga diharapkan memberi pengawasan dalam membentuk kepribadian di sekolah dan dapat mengurangi kebiasaan tidak mencuci tangan pada murid.

Kata Kunci: Pengetahuan, Kebiasaan, Mencuci tangan

\section{PENDAHULUAN}

Pengetahuan merupakan hasil tahu, dan ini terjadi setelah orang melakukan pengindraan terhadap suatu objek tertentu. Pengindraan terjadi melalui pancaindra manusia, yakni indera penglihatan, pendengaran, penciuman, rasa, dan raba. Sebagian besar pengetahuan manusia diperoleh melalui mata dan telinga. Pengetahuan atau ranah kognitif merupakan domain yang sangat penting dalam membentuk tindakan seseorang (over behavior) (Notoatmodjo,2012 : 138).

Pengetahuan ini bertujuan untuk mengelompokkan tingkah laku masyarakat atau individu yang diinginkan. Bagaimana individu itu berfikir, berbuat sebagai suatu unit pengetahuan yang diberikan. Pengetahuaan sangat berpengarah 
terhadap pencapaian derajat kesehatan seseorang. (Wawan : 2011)

Terwujudnya derajat kesehatan masyarakat tersebut dapat dicapai, salah satunya dengan program Perilaku Hidup Bersih dan Sehat (PHBS). Perilaku Hidup Bersih dan Sehat adalah semua perilaku kesehatan yang dilakukan atas kesadaran sehingga anggota keluarga atau keluarga dapat menolong dirinya sendiri di bidang kesehatan dan berperan aktif dalam kegiatankegiatan kesehatan di masyarakat. Salah satu indikator dari Perilaku Hidup Bersih dan Sehat adalah CTPS. Cuci Tangan Pakai Sabun (CTPS) adalah salah satu tindakan sanitasi dengan membersihkan tangan dan jari-jemari menggunakan air dan sabun untuk menjadi bersih. Mencuci tangan dengan sabun merupakan salah satu upaya pencegahan penyakit. Hal ini dilakukan karena tangan seringkali menjadi agen yang membawa kuman dan menyebabkan patogen berpindah dari satu orang ke orang lain, baik dengan kontak langsung ataupun tidak langsung (Setyaningrum, dkk. 2015).

Kebiasaan mencuci tangan dengan sabun adalah bagian dari perilaku hidup sehat yang merupakan salah satu dari tiga pilar pembangunan bidang kesehatan yakni perilaku hidup sehat, penciptaan lingkungan yang sehat serta penyediaan layanan kesehatan yang bermutu dan terjangkau oleh semua lapisan masyarakat. Perilaku hidup sehat yang sederhana seperti mencuci tangan dengan sabun merupakan salah satu cara untuk meningkatkan kesadaran masyarakat tentang pemeliharaan kesehatan pribadi dan pentingnya berperilaku hidup bersih dan sehat. Cuci tangan sering dianggap sebagai hal yang sepele di masyarakat adalah cuci tangan bisa memberi kontribusi pada peningkatan status kesehatan masyarakat. Berdasarkan fenomena yang ada terlihat bahwa anak-anak usia sekolah mempunyai kebiasaan kurang memperhatikan perlunya cuci tangan dalam kehidupan sehari-hari, terutama ketika di lingkungan sekolah. Mereka biasanya langsung makan makanan yang mereka beli di sekitar sekolah tanpa cuci tangan terlebih dahulu, padahal sebelumnya mereka bermain-main (Purwandari, dkk. 2013).

Perilaku tersebut tentunya berpengaruh dan dapat memberikan kontribusi dalam terjadinya penyakit diare dan infeksi. Cuci tangan merupakan tehnik dasar yang paling penting dalam pencegahan dan pengontrolan penularan infeksi. Penelitian yang dilakukan oleh Luby, Agboatwalla, Bowen, Kenah, Sharker, dan Hoekstra (2009), mengatakan bahwa cuci tangan dengan sabun secara konsisten dapat mengurangi diare dan penyakit pernafasan.

Cuci tangan pakai sabun (CTPS) dapat mengurangi diare sebanyak $31 \%$ dan menurunkan penyakit infeksi saluran nafas atas (ISPA) sebanyak $21 \%$. Riset global juga menunjukkan bahwa kebiasaaan CTPS tidak hanya mengurangi, tapi mencegah kejadian diare hingga $50 \%$ dan ISPA hingga 45\% (Fajriyati, 2013). Penelitian oleh Burton, Cobb, Donachie, Judah, Curtis, dan Schmidit (2011) menunjukkan bahwa cuci tangan dengan menggunakan sabun lebih efektif dalam memindahkan kuman dibandingkan dengan cuci tangan hanya dengan mengggunakan air. Masyarakat menganggap CTPS tidak penting, mereka cuci tangan pakai sabun ketika tangan berbau, berminyak dan kotor.

Tangan adalah bagian tubuh kita yang paling banyak tercemar kotoran 
dan bibit penyakit. Ketika memegang sesuatu, dan berjabat tangan, tentu ada bibit penyakit yang melekat pada kulit tangan kita. Telur cacing, virus, kuman dan parasit yang mencemari tangan, akan tertelan jika kita tidak mencuci tangan dulu sebelum makan atau memegang makanan. Dengan cara demikian umumnya penyakit cacing menulari tubuh kita. Di samping itu, bibit penyakit juga dapat melekat pada tangan kita setelah memegang uang, memegang pintu kamar mandi, memegang gagang telepon umum, memegang mainan, dan bagian-bagian di tempat umum (Potter \& Perry, 2005). Melalui tangan kita sendiri segala bibit penyakit itu juga bisa memasuki mulut, lubang hidung, mata, atau liang telinga, karena kebiasaan memasukkan jari ke hidung, mengucek mata, mengorek liang telinga, bukan pada waktu yang tepat (pada saat tangan kotor), dan ketika jari belum dibasuh (belum cuci tangan). Hasil penelitian oleh kemitraan pemerintah dan swasta tentang CTPS menunjukkan bahwa pengetahuan masyarakat tentang CTPS sudah tinggi, namun praktik di lapangan masih rendah. (Mikail, 2011).

Indonesia juga telah menggelar kembali Hari Cuci Tangan Pakai Sabun (HCTPS) pada 15 Oktober. Cuci tangan dengan sabun merupakan bagian penting karena kegiatan ini sebagai implementasi dari paradigma baru dalam pelaksanaan program-program kesehatan. HCTPS ini menjadi moment penting untuk meningkatkan budaya cuci tangan pakai sabun di keluarga Indonesia yang tergolong masih rendah, sebab cuci tangan pakai sabun adalah salah satu cara yang paling efektif untuk mencegah penyebaran kuman penyakit masuk ke dalam sistem imunitas tubuh. Cuci tangan menurut Tietjen, et al merupakan proses membuang kotoran dan debu secara mekanis dari kulit kedua belah tangan dengan memakai sabun dan air. Tangan adalah media utama bagi penularan kuman-kuman penyebab penyakit. Akibat kurangnya kebiasaan cuci tangan, anak-anak menjadi penderita tertinggi dari penyakit diare dan pernafasan, hingga tidak jarang berujung dengan kematian (Khoiruddin, dkk. 2015).

Jumlah anak yang meninggal dunia di dunia akibat penyakit Infeksi Diare turun sepertiga tahun 20052015. Studi The Lancet menyatakan, akses lebih baik pada air bersih dan sanitasi jadi kunci, dengan lebih sedikit anak yang mengalami malnutrisi terinfeksi. Vaksin baru juga berdampak positif. Namun, Diare menjadi salah satu penyebab utama kematian bayi secara Global, hampir 500.000 anak meninggal tiap tahun sebelum berusia lima tahun. Diare juga memperburuk penyakit lain seperti pneumonia dan campak. Sejumlah Periset Amerika Serikat yang menganalisis data dari studi baru Beban Global Penyakit menemukan, lebih dari sepertiga (42\%) kematian terjadi di Nigeria dan India. Diare seperti Rotavirus dan Kolera menyebar lewat pencemaran air dengan feses.

Pada tahun 2020 penemuan diare di Provinsi Jambi berjumlah 94.949 kasus yang tersebar pada 11 kabupaten/ kota. Jika dibandingkan tahun 2019, terjadi peningkatan kasus dimana penderita Diare berjumlah 64.308. Pada tahun 2018 penemuan penderita Diare di Provinsi Jambi berjumlah 72.108 kasus Dilihat pada tahun 2017 kasus Diare di Provinsi Jambi dari 11 kabupaten/ kota berjumlah sebesar 90.757 kasus. Jika dibandingkan dengan tahun 2016 
(84.188 kasus) terjadi peningkatan sebesar $1,5 \%$ (1.213 kasus).

Sedangkan di Kecamatan Hamparan Rawang menurut buku kunjungan klien usia 7-12 tahun di Puskesmas Hamparan Rawang didapatkan data pada tahun 2019 data ISPA sebanyak 688 orang, Demam sebanyak 111 orang, Influenza sebanyak 25 orang, dan Diare sebanyak 55 orang. Pada tahun 2020 didapatkan data ISPA sebanyak 597 orang, Demam sebanyak 162 orang, Influenza sebanyak 32 orang, dan Diare sebanyak 47 orang. Dan pada bulan Januari - Agustus 2021 didapatkan data ISPA sebanyak 247 orang, Demam sebanyak 122 orang, Influenza sebanyak 4 orang, dan Diare sebanyak 26 orang.

Berdasarkan survey awal pada tanggal 5 Agustus 2021 dengan melakukan wawancara terpimpin saya menemui 10 responden. 7 diantaranya tidak memiliki kebiasaan yang baik dan 3 diantaranya mempunyai kebiasaan yang baik .

Berdasarkan latar belakang diatas maka rumusan masalah pada penelitian ini "Apakah ada Hubungan Pengetahuan Murid dengan kebiasaan mencuci tangan di SDN NO. 30/XI Koto Dian Kec. Hamparan Rawang Kota Sungai Penuh?

Penelitian ini dapat memberikan pedoman praktis kepada Guru dalam pengambilan keputusan kebijakan yang berkaitan dengan mencuci tangan dalam memberikan masukan atau binaan terhadap anak muridnya.

\section{METODE PENELITIAN.}

Penelitian ini bersifat deskriptif analitik dengan desain penelitian Cross Sectional, yaitu suatu penelitian untuk mempelajari dinamika korelasi antara faktor - faktor risiko (variabel independen) dengan efek (variabel dependen), dengan cara pendekatan, observasi atau pengumpulan data sekaligus pada suatu saat (point time approach), dimana variabel dependen dan variabel independen yang diukur sekaligus pada saat yang bersamaan. (Notoatmodjo, 2012 : 49)

Populasi adalah keseluruhan subjek (misalnya manusia, klien) yang memenuhi kriteria yang telah ditetapkan. (Nursalam, 2008 : 89). Populasi dalam penelitian ini adalah seluruh Murid kelas III - VI SDN No. 30/XI Koto Dian Kec. Hamparan Rawang Kota Sungai Penuh yaitu berjumlah 71 orang pada tahun 2021 ini didasarkan dikarenakan kondisi pembelajaran saat itu dibagi oleh pihak sekolah, dimana kelas I-III belajar secara during dan yang tatap muka hanya kelas III-VI saat itu, itupun dibagi shif.

Sampel penelitian yang dilakukan sebanyak 54 sampel dari kelas III -VI Teknik Pengambilan Sampel yang dilakukan dalam penelitian ini adalah Accidental Sampling.

Kriteria sampel dalam penelitian ini Murid kelas III - VI yang ada di SDN No. 30/XI Koto Dian Kec. Hamparan Rawang, Bersedia menjadi responden, Kooperatif dengan peneliti, Penelitian ini dilaksanakan di SDN No. 30/XI Koto Dian Kec. Hamparan Rawang, dan penelitian ini dilaksanakan 09 Oktober 2021.

Adapun etika penelitian yang peneliti laksanakan antara dengan responden penelitian dengan memberikan lembar persetujuan. Tujuan informed consent adalah agar subjek mengerti maksud dan tujuan penelitian yaitu untuk mengetahui Hubungan Tingkat Pengetahuan Murid tentang Mencuci Tangan, serta dampak yang akan terjadi selama dalam pengumpulan data yaitu waktu 
Responden terganggu. Jika responden bersedia diteliti mereka harus menandatangani lembar persetujuan tersebut, jika tidak peneliti harus menghormati hak-hak responden.

Adapun Informasi yang telah dikumpulkan dari subjek dijamin kerahasiaannya. Kerahasiaan informasi responden mengenai Hubungan Tingkat Pengetahuan Murid SD dengan kebiasaan mencuci tangan di SDN No. 30/XI Koto Dian Kec. Hamparan Rawang Kota Sungai Penuh hanya dapat dipublikasikan atau digunakan oleh peneliti lain mendapat izin oleh peneliti.

Teknik pengumpulan data peneliti peroleh dengan mengumpulkan data primer dan data sekunder: dengan menggunakan kuesioner, informed consent dan wawancara. Dimana kuesioner sebelumnya sudah diuji validitas dan reabilitas yang dilakukan di SDN No.043/XI Koto Renah Kota Sungai Penuh dan Penguji realibilitas di mulai dengan menguji validitas terebih dahulu. Jadi jika pertanyaan tidak valid, maka pertanyaan tersebut dibuang atau diperbaiki. Hasil dari uji reabilitas tingkat pengetahuan murid dalam penelitian ini dengan Cronbach's Alpha 0,879 dan kebiasaan mencuci tangan dengan Cronbach's Alpha 0,945.

Kuesioner merupakan sejumlah pertanyaan tertulis yang digunakan untuk memperoleh informasi dari responden. Kuesioner yang digunakan adalah pertanyaan terstruktur untuk mengambil data dan mengetahui tingkat pengetahuan murid SD dengan kebiasaan mencuci tangan. Untuk mempermudah analisis data dilakukan kepercayaan 95\% $(a=0,05)$. dengan hasil analisa penelitian ini pemberian skor pada setiap pertanyaan.

Pengolahan data pada penelitian ini mulai dengan (Editing) pengecekan dan perbaikan isian kuisioner dilanjutkan dengan pemberian code setelah semua data diedit atau disunting, selanjutnya dilakukan pengkodean atau coding, yakni mengubah data berbentuk kalimat atau huruf menjadi data angka atau bilangan. Selanjutnya dengan penskoringan dimana peneliti memberi skor untuk masing masing pertanyaan dan selanjutnya memasukkan data yang sudah dilakukan pengkodean kedalam program komputer SPSS dan dilanjutkan Tabulating atau Memasukkan data dari hasil penelitian ke dalam tabel-tabel sesuai kriteria dan terkahir di cleaning. kegiatan pengecekan kembali untuk melihat kemungkinan-kemungkinan adanya kesalahan-kesalahan kode, kemudian dilakukan pembentulan atau koreksi.

Teknik analisa data dalam penelitian ini dengan menggunakan Analisa univariat yang dilakukan secara deskriptif atau melihat gambaran distribusi frekuensi masingmasing variabel yaitu Tingkat Pengetahuan dan Kebiasaan Mencuci Tangan dan analisa bivariat untuk menguji hipotesa apakah ada hubungan tingkat pengetahuan Murid SD tentang kebiasaan mencuci tangan. Tujuan analisa bivariat ini adalah untuk melihat hubungan variabel dependen dan idependen dengan menggunakan uji chi-square pada pengolahan data dengan program SPSS, dengan derajat menunjukan hubungan yang bermakna dimana nilai $p$ value $<0,05$ 


\section{HASILPENELITIAN}

Analisis Univariat

Tabel 1. Distribusi Frekuensi Pengetahuan Murid Kelas III -VI di SDN No.30/XI Koto Dian dan kebiasaan Kec. Hamparan Rawang Kota Sungai Pen

\begin{tabular}{ccc} 
Pengetahuan & Frekuensi & Persentase $\%$ \\
\hline Kurang & 31 & 57,4 \\
Baik & 23 & 42,6 \\
Total & 54 & 100,0 \\
\hline Kebiasaan & Frekuensi & Persentase $\%$ \\
\hline Tidak Baik & 30 & 55,6 \\
Baik & 24 & 44,4 \\
Total & 54 & 100,0 \\
\hline
\end{tabular}

Tabel 1 diatas menunjukkan bahwa dari 54 responden terdapat sebagian besar responden yaitu 31 responden $(57,4 \%)$ berpengetahuan kurang baik dan 23 responden $(42,6 \%)$ berpengetahuan baik di SDN No. 30/XI Koto Dian Kec. Hamparan Rawang Kota Sungai Penuh Tahun 2021.
Tabel di atas juga menunjukkan bahwa dari 54 responden sebagian besar yaitu 30 responden $(55,6 \%)$ memiliki kebiasaan yang tidak baik dan 24 responden $(44,4 \%)$ memiliki kebiasan tidak baik di SDN No. 30/XI Koto Dian Kec. Hamparan Rawang Kota Sungai Penuh Tahun 2021.

\section{Analisa Bivariat}

Tabel 1.2 Distribusi Frekuensi Pengetahuan Murid Kelas III - VI di SDN No.30/XI Koto Dian dan kebiasaan Kec. Hamparan Rawang Kota Sungai Penuh

\begin{tabular}{|c|c|c|c|c|c|c|c|c|}
\hline \multirow{3}{*}{$\begin{array}{c}\text { Kebiasaan } \\
\text { Mencuci } \\
\text { Tangan }\end{array}$} & \multicolumn{4}{|c|}{ Pengetahuan } & \multirow{2}{*}{\multicolumn{2}{|c|}{ Jumlah }} & \multirow{3}{*}{$\begin{array}{c}\mathbf{P} \\
\text { Value }\end{array}$} & \multirow{2}{*}{ OR } \\
\hline & \multicolumn{2}{|c|}{ Kurang } & \multicolumn{2}{|c|}{ Baik } & & & & \\
\hline & $f$ & $\%$ & $f$ & $\%$ & $f$ & $\%$ & & \\
\hline Tidak baik & 22 & 73,3 & 8 & 26,7 & 30 & 100 & & \\
\hline Baik & 9 & 37,5 & 15 & 62,5 & 24 & 100 & 0,018 & 4,583 \\
\hline Total & 31 & & 23 & & 54 & 100 & & \\
\hline
\end{tabular}

Tabel 2. diatas menunujukan bahwa responden yang memiliki kebiasaan mencuci tangan tidak baik dengan pengetahuan kurang yaitu 22 responden $(73,3 \%)$ dibandingkan dengan kebiasaan mencuci tangan tidak baik berpengetahuan baik yaitu 8 responden $(26,7 \%)$. Sedangkan yang memiliki kebiasaan mencuci tangan baik dengan pengetahuan kurang baik yaitu 9 responden $\quad(37,5 \%)$ dibandingkan dengan yang memiliki kebiasaan mencuci tangan baik dengan pengetahuannya baik yaitu 15 responden $(62,5 \%)$. Berdasarkan hasil analisis statistik dengan uji chi square diperoleh $\mathrm{p}$ value 0,018 dengan derajat kemaknaan $95 \%(\propto=0,05)$. Hal ini dapat disimpulkan bahwa ada hubungan tingkat pengetahuan murid 
dengan kebiasaan mencuci tangan di SDN No.30/XI Koto Dian Kec. Hamparan Rawang Kota Sungai Penuh Tahun 2017. Kemudian diperoleh nilai Odds Ratio = 4,583 artinya pengetahuan rendah mempunyai peluang 4 kali menyebabkan kebiasaan mencuci tangan tidak baik dibanding kebiasaan mencuci tangan yang baik. Sehingga murid harus diberikan penyuluhan yang baik tentang pentingnya cuci tangan.

\section{PEMBAHASAN}

Hubungan Pengetahuan Murid SD Kelas III - VI Dengan Kebiasan Mencuci Tangan di SDN 30/XI Koto Dian Kec. Hamparan Rawang

\section{Analisa Univariat}

Hasil pengatahuan yag diperoleh dari hasil penelitian dapat dilihat bahwa terdapat $57,4 \%$ responden dengan pengetahuan kurang dan $42,6 \%$ responden memiliki pengetahuan baik tentang mencuci tangan, berdasarkan analisis kuesioner responden yang pengetahuan kurang baik adanya ketidaktahuan responden tentang mencuci tangan karena responden tidak pernah/jarang mendapatkan promosi kesehatan tentang mencuci tangan.

Hal ini sama dengan penelitian yang dilakukan oleh Inayatur Rabbani, dkk (2013) yang berjudul hubungan pengetahuan terhadap perilaku cuci tangan petugas kesehatan di bagian ilmu kesehatan anak Blu RSUP Prof. Dr. Rd. Kandou Manado, hasil yang didapatkan bahwa responden yang memiliki pengetahuan kurang baik sebanyak 55 orang (70,5\%), pengetahuan baik 14 orang $(17,9 \%)$, dan pengetahuan buruk 9 orang $(11,5 \%)$.
Disamping itu menurut penelitian Ahmad Ridwan, dkk (2015) hubungan tingkat pengetahuan tentang cuci tangan dengan kejadian diare pada balita, hasil yang didapatkan bahwa responden memiliki pengetahuan baik 23 orang $(43,4 \%)$, cukup 22 orang (41.5\%), kurang 7 orang $(13,2 \%)$, tidak baik 1orang $(1,9 \%)$.

Hal ini sesuai dengan teori yang disebutkan oleh Notoatmodjo (2012) Pengetahuan murid yang kurang tentang mencuci tangan dipengaruhi oleh informasi yang didapatkan oleh murid tentang cuci tangan. Pengetahuan merupakan hasil dari tahu, dan ini terjadi setelah orang melakukan pengindraan terhadap suatu objek tertentu. Pengindraan terjadi melalui pancaindra manusia, yakni indra penglihatan, pendengaran, penciuman, rasa dan raba. Sebagian besar pengetahuan manusia diperoleh melalui mata dan telinga.

Menurut asumsi peneliti bahwa adanya ketidaktahuan responden tentang mencuci tangan karena responden tidak pernah/jarang mendapatkan promosi kesehatan tentang mencuci tangan. Saat ditanyakan waktu mencuci tangan, responden hanya menjawab sebelum dan sesudah makan. Padahal masih banyak aktifitas-aktifitas yang perlu dilakukan cuci tangan. Seperti setelah bermain, sebelum dan setelah BAB/BAK, sebelum dan setelah mengorek liang hidung/telinga, dan lain-lain.

Dari hasil penelitian kebiasaan mencuci tangan yang dilakukan terdapat 30 responden $(55,6 \%)$ memiliki kebiasaan mencuci tangan tidak baik dan 24 responden $(44,4 \%)$ memiliki kebiasaan mencuci tangan baik. Hal ini di dukung oleh penelitian yang dilakukan oleh Warni Listiyorini 
(2012) yang berjudul hubungan antara kebiasaan mencuci tangan anak pra sekolah dengan kejadian Diare di wilayah kerja Puskesmas Pajang Surakarta di Fakultas IImu Kesehatan Universitas Muhammadyah Surakarta, hasil yang di dapatkan kebiasaan mencuci tangan baik 17 orang $(21 \%)$, kebiasaan mencuci tangan cukup baik $41(50,6 \%)$, dan kurang baik 23 orang $(28,4 \%)$. Disamping itu menurut Winda Sari, dkk (2014) gambaran pengetahuan dan sikap siswa terhadap perilaku hidup bersih dan sehat dengan cuci tangan pakai sabun di Yayasan Perguruan Tut Wuri Handayani Di Mabar Kecamatan Medan Deli, hasil yang didapatkan tindakan responden tidak pernah mencuci tangan 3 orang $(8,3 \%)$, kadang-kadang 22 orang $(61,1 \%)$, Selalu 11 orang $(30,6 \%)$

Cuci tangan adalah proses pembuangan kotoran dan debu secara mekanis dari kulit kedua belah tangan dengan memakai sabun dan air mengalir. Tujuannya adalah menghilangkan kotoran dan debu secara mekanis dari permukaan kulit dan mengurangi jumlah mikroorganisme sementara. Cuci tangan dengan sabun biasa dan air sama efektifnya dengan cuci tangan menggunakan sabun anti mikrobial, iritasi kulit jauh lebih rendah apabila menggunakan sabun biasa (Yulrina, dkk, 2014: 243).

Menurut Hendrawan Nadesrul (2011:76), dengan mencuci tangan yang benar, khususnya penyakit perut (tifus, kolera, disenteri) selain resiko tertular virus hepatitis, flu burung, SARS (Severe Acute Respiratory Syndrome), dapat dicegah. Selain itu dengan mcmbiasakan mencuci tangan dapat membatalkan jangkitan sejumlah penyakit virus lainnya yang ditularkan melalui pernapasan, yang berlangsung saat jari kotor (sudah tercemar bibit penyakit) mengorekngorek liang hidung. Atau virus yang menular lewat pencernaan akibat tercemar saat menggigiti kuku jari atau sehabis memegang pegangan pintu kamar kecil lalu tidak membasuh tangan. Pada jemari yang kelihatannya serba bersih pun, belum tentu steril. Bisa jadi terselip bibit penyakit. Bisa virus, kuman, atau telur cacing (yang tersebar di permukaan tanah yang sudah tercemar telur cacing perut).

Menurut asumsi peneliti bahwa kebiasaan mencuci tangan yang tidak baik disebabkan karena sebagian besar murid SD lebih cenderung makanmakanan tanpa mencuci tangan dan sudah menjadi kebiasaan bahwa tangan yang terlihat bersih tidak perlu dicuci lagi. Responden tidak memahami pentingnya mencuci tangan, mereka menganggap cuci tangan hal yang sepele. Sehingga responden tidak melakukan cuci tangan yang benar, mencuci tangan menggunakan air saja.

\section{Analisa Bivariat}

Dari hasil penelitian menunjukkan bahwa persentase Murid SD dengan pengetahuan kurang baik cenderung mengalami kebiasaan mencuci tangan tidak baik sebanyak $73,3 \%$, pengetahuan yang baik cenderung mengalami kebiasaan mencuci tangan tidak baik sebanyak $26,7 \%$. Hasil uji statistik chi-square dengan derajat kemaknaan 95\% didapatkan nilai $\mathrm{p}<0,05$ atau $\mathrm{p}=$ 0,018 artinya dapat ditarik kesimpulan bahwa ada hubungan antara pengetahuan dengan kebiasaan mencuci tangan di SDN No.30/XI Koto Dian Kec. Hamparan Rawang Kota Sungai Penuh Tahun 2017. Hal ini dapat dibuktikan dari jawaban 
responden bahwa lebih dari separoh responden yang pengetahuan kurang baik memiliki kebiasaan mencuci tangan serta hanya sedikit responden yang pengetahuan baik memiliki kebiasaan mencuci tangan.

Hasil penelitian ini sama dengan penelitian yang dilakukan oleh Dwi Hastuti (2015) yang menyatakan ada hubungan antara tingkat pengetahuan dengan kebiasaan mencuci tangan dengan nilai $p=0,046$ dan $p=0,022$. Disamping itu menurut penelitian I Gusti Made Jelantik (2015) dengan judul Hubungan pengetahuan, sikap dan ketersediaan sarana dengan kebiasaan cuci tangan pakai sabun untuk mencegah diare dan Ispa pada ibu rumah tangga dikelurahan Ampenan Tengah Kota Mataram, hasil yang didapat Bedasarkan hasil uji statistik dengan Uji Sperman's Rho diketahui nilai probabilitas $=0,009<a$ 0,05, yang berarti bahwa ada hubungan bermakna antara hubungan pengetahuan dengan kebiasaan cuci tangan pakai sabun pada ibu rumah tangga.

Notoatmodjo

mengatakan pengetahuan merupakan hasil dari tahu, dan ini terjadi setelah orang melakukan pengindraan terhadap suatu objek tertentu. Pengindraan terjadi melalui pancaindra manusia, yakni indra penglihatan, pendengaran, penciuman, rasa dan raba. Sebagian besar pengetahuan manusia diperoleh melalui mata dan telinga. Pengetahuan Murid yang kurang akan kebiasaan mencuci tangan juga dipengaruhi oleh informasi yang didapatkan oleh murid tentang kebiasaan mencuci tangan.

Tingkat Pengetahuan Tahu (Know), Memahami (comprehension), Aplikasi (aplication), Analisis (analysis), Sintesis (syntesis), Evaluasi (evaluation) Menurut (Notoatmodjo 2012). Dilihat dari kategori tingkatan pengetahuan responden yang diteliti dimana lebih dari separoh responden memiliki tingkat pengetahuan rendah, maka dapat kita simpulkan bahwa pengetahuan responden di SDN No.30/XI Koto Dian Kec. Hamparan Rawang Kota Sungai Penuh hanya sebatas tahu saja, artinya responden mengetahui tentang mencuci tangan namun belum mamahami apa itu cuci tangan yang sebenarnya sehingga banyak responden yang tidak mengaplikasikan pengetahuan mereka.

Menurut asumsi peneliti bahwa tingkat pengetahuan kurang baik dapat mempengaruhi kebiasaan mencuci tangan yang tidak baik dimana pada penelitian ini diperoleh hasil bahwa peluang murid putra dan putri dengan tingkat pengetahuan kurang 4,259 kali lebih beresiko memiliki kebiasaan mencuci tangan tidak baik dibandingkan murid yang memiliki pengetahuan baik.

\section{KESIMPULAN}

Kesimpulannya adalah ada hubungan antara tingkat pengetahuan dengan kebiasaan mencuci tangan di SDN No.30/XI Koto Dian Kec. Hamparan Rawang Kota Sungai Penuh. 


\section{DAFTAR PUSTAKA}

Depkes. (2010). 5 Waktu Penting Cuci Tangan dengan Sabun. Kementerian Kesehatan RI.

Depkes. (2011). Panduan Manajemen PHBS Menuju Kabupaten/Kota Sehat. Jakarta: Depkes RI

Dinas Kesehatan Provinsi Jambi. (2020). Laporan Akuntabilititas Kinerja instansti Program Pencegahan Dan Pengendalian Penyakit. https://e-renggar. kemkes.go. Id/file2018/eperformance/ 1-1090022tahunan-619.pdf

Djauzi, samsuridjal. (2009). Raih Kembali Kesehatan Kembali Mencegah Berbagai Penyakit, Hidup Sehat Untuk Keluarga. Jakarta: Buku Kompas

Yunita, dkk (2018) Gambaran Tingkat Pengetahuan Siswa Siswi Kelas 2 dan 3 tentang Perilaku Hidup Bersih dan Sehat Mencuci Tangan di SD 030 Kecamatan Muara Kaman Kabupaten Kutai Kartanegara.

https://dspace.umkt.ac.id/han dle/463.2017/583

Hidayat, A. Alimul. (2013). Metodologi Penelitian Keperawatan dan Teknik Analisa Data. Jakarta: Salemba

Jelantik, Geria. (2015). Hubungan Tingkat Pengetahuan, Sikap dan Ketersediaan Sarana Dengan Kebiasaan Cuci Tangan Pakai Sabun Untuk Mencegah Diaredan ispa Pada Ibu Rumah Tangga di kelurahan ampenan tengah Kota Mataram

Khoiruddin, dkk. (2015). Tingkat Pengetahuan Berhubungan dengan Sikap Cuci Tangan Bersih Pakai Sabun Sebelum dan Setelah Makan pada Siswa SDN Ngebel, Tamantirta, Kasihan. https://ejournal.almaata.ac.id /index.php/JNKI/article/view/ 175

Kusrini. (2006). Sistem Pakar Teori dan Aplikasi. Yogyakarta: Andi Offset

Listiyorini, Warni. (2012). Hubungan Antara Kebiasaan Mencuci Tangan Anak Pra Sekolah Dengan Kejadian Diare Di Wilayah Kerja Puskesmas Pajang Surakarta.http://eprints.ums.a c.id/22549/

Mubarak. (2010). Promosi Kesehatan Untuk Kebidanan. Jakarta: Salemba

Nadesrul, hendrawan. (2011). Sehat Itu Murah. Jakarta: buku kompas

Notoatmojo. (2012). Metodologi Penelitian Kesehatan. Jakarta: Rineka Cipta

Notoatmojo. (2012). Promosi Kesehatan dan Perilaku Kesehatan. Jakarta: Rineka Cipta

Hafani, Nur dkk (2017) Hubungan pengetahuan mencuci tangan dengan kejadian diare pada siswa kelas IV-VI SDN 11 Lubuak Buaya Padang. http://jurnal.fk.unand.ac.id/in dex.php/jka/article/view/705

Nursalam. (2008). Konsep dan Penerapan Metodologi Penelitian Ilmu Keperawatan. Jakarta: Salemba Medika

Pauzan, dkk (2017) Hubungan Pengetahuan dengan perilaku cuci tangan siswa di Sekolah Dasar Negri Cidadas 2 Kota Bandung.

https://ejournal.bsi.ac.id/ejur nal/index.php/jk/article/view/ 1458

Purwandari, Retno. (2013). Hubungan AntAra Perilaku Mencuci Tangan dengan Insiden Diare pada Anak Usia Sekolah Di Kabupaten 
Jember.https://ejournal.umm. ac.id/index.php/keperawatan/ article/view/2362

Rabbani, Inayatur. (2013). Hubungan Pengetahuan Terhadap Perilaku Cuci Tangan Petugas Kesehatan Di Bagian Ilmu Kesehatan Anak BLU RSUP PROF DR RD KANDOU MANADO.https: / / ejournal.unsra t.ac.id/index.php/eclinic/articl e/view/3661

Rosyidah, Alif (2019). Hubungan Perilaku Cuci Tangan Terhadap Kejadian Diare Pada Siswa di Sekolah Dasar Negeri Ciputat 02. http://ejournal.akperfatmawati .ac.id/index.php/JIKO/article/v iew/25

Sari, Winda. (2014). Gambaran Pengetahuan dan Sikap Terhadap Perilaku Hidup Bersih Dan Sehat Dengan Cuci Tangan Pakai Sabun di Yayasan Perguruan Tut Wuri Handayani di Mabar Kecamatan Medan

Deli.https://www.neliti.com/pu blications / 14364/

Setyaningrum, Ratna. (2015). Tingkat Pengetahuan dan Sikap Tentang Cuci Tangan Pakai Sabun (Ctps) Pada Siswa SDN Batuah I dan Batuah III Pagatan. https://ppjp.ulm.ac.id/journal /index.php/berkalakesehatan/article/view/660/0

Sunaryo. (2004). Psikologi Untuk Keperawatan. Jakarta: EGC

Sursilah, ilah. (2010). Pencegahan Infeksi dalam Pencegahan Kebidanan. Yogyakarta: Dee Publish

Susanto. (2007). Metodologi Penelitian: Jakarta: UI

Wawan, A \& Dewi, M. (2011). Teori dan pengukuran pengetahuan, siakp dan perilaku manusia.Yogyakarta : Nuha Medica

Wirawan, I. Made C. (2013). Kata dokter. Jakarta Selatan: Panda Media

Yulrina, dkk. (2014). Panduan Lengkap Keterampilan Dasar Kebidanan I. Yogyakarta: Deepublish 